\title{
'The church should teach us to do respect': Voices from rural youth in Mpumalanga, South Africa
}

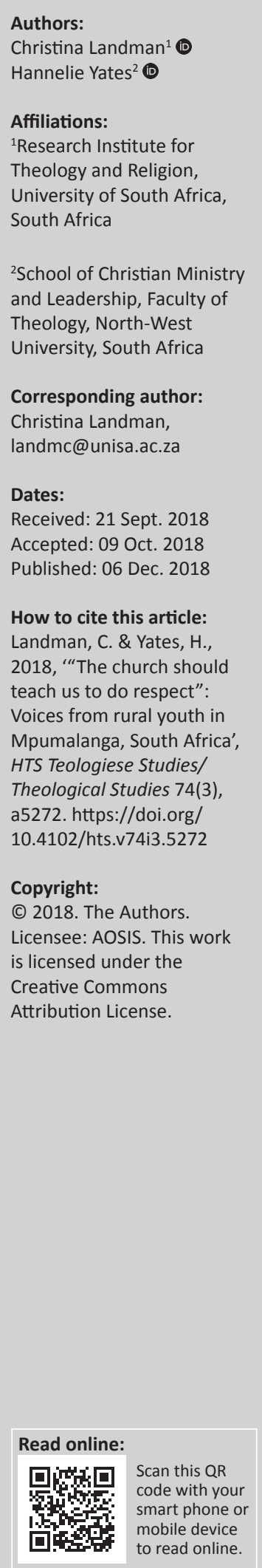

During research conducted between December 2013 and November 2017 with young people in Sakhelwe and Emthonjeni, the 'townships' of Dullstroom-Emnotweni and Machadodorp in the east of South Africa, the youth themselves placed 'respect' on the research agenda as a value to be discussed with their churches. This article therefore focuses on this 'discussion'. Additional research was conducted with a third research population, that is, with the youth in Siyathuthuka, the 'township' of Belfast. The latter is an adjacent town which, because of mining activities, is affluent in comparison with Sakhelwe and Emthonjeni. This article explores definitions and meanings of 'respect' as voiced by five young people from Sakhelwe, three from Emthonjeni and seven from Siyathuthuka. These voices are supplemented with voices from the youth expressed in the previous research conducted between 2013 and 2017. After having explored to what extent the youth saw 'respect' as a religious value, their voices are retrieved on their expectations of how their churches can influence society towards the youth being respected and respecting. It is explored to what extent the youth, in a poor and marginalised rural community such as Sakhelwe, in comparison to a more affluent semi-urbanised community such as Siyathuthuka, allowed the church to bring a corrective on the dominant discourse amongst the youth that 'money, sex, violence and political activism bring respect'.

\section{Introduction}

\section{Background: 'Respect' amongst rural youth}

In their study amongst rural youth in the eastern South African province of Mpumalanga, Sennott and Mojola (2017:781-795) indicate that, even in the midst of growing cultural disintegration, rural young women strive for respectability in their communities through transition rituals that define them as 'proper mothers'. However, they simultaneously deconstruct the traditional discourses supporting 'proper motherhood', reconstructing them towards becoming educated and financially independent, and engage in own-choice sexual behaviour. The young women voiced their opinion that the youth can be educated, financially independent and sexually liberated; however, they themselves (albeit reluctantly) acknowledge that if they do not 'behave well' in terms of emic norms, they will not be respected.

In this study, which was also conducted in rural townships in Mpumalanga, we hypothesise to find both similar and different meanings of respectability amongst rural youth. The hypothesis is as follows: within the absence of parental role models, marriage opportunities and tertiary education, as is the case in the marginalised townships of Sakhelwe (Dullstroom-Emnotweni) and Emthonjeni (Machadodorp- eNktokozweni), 'respect' is defined in terms of money, sex, violence and political activism. Where opportunities of education, employment and marriage exist, 'respect' assumes the form of acknowledgement and self-expression, as is the case in the more affluent township of Siyathuthuka. This opens up challenges for the churches to journey with the youth towards alternative styles of demanding and showing respect.

\section{Aim of the study}

The aim of this study is twofold. Firstly, the voices of rural youth will be quoted, without being mediated through interpretation, in which they express their views on 'respect' within their specific contexts. From these voices, the dominant discourses on 'respectability' will be deduced. Secondly, their expectations of what their churches can do to reconstruct the present discourse on respectability as a religious value will be described. Religious discourses deconstructing the dominant discourse of respect as obtained by money, sex, violence and political activism will be considered vis-à-vis the voices of the youth. 


\section{Research questions, research population and context}

From 2013 to 2017, we conducted research with young people between the ages of 18 and 24 years in the rural townships of Sakhelwe (Dullstroom-Emnotweni) and Emthonjeni (Machadodorp-eNktokozweni) in Mpumalanga in the east of South Africa. The research was conducted as part of the Youth on the Margins (YOMA) project hosted by the University of South Africa and on the Nordic side Uppsala University, University of Helsinki and VID Specialised University in Norway. The aim of the latter research was to explore the relationship between marginalised youth and faith-based organisations (FBOs) with a view towards the expectations of the youth vis-à-vis FBOs and the latter's possible role of effecting social cohesion. ${ }^{1}$

During the YOMA research, the research participants pointed to 'respect' as a religious value that they expected from the FBOs to transfer to their young members (Landman \& Yates 2018). Under 'to do respect', they expected to co-construct values with the FBOs in order for them both to give and to demand respect.

Consequently, we placed the religious value of 'respect' as expected from the FBOs on the research agenda for this article. Furthermore, we undertook additional research in Siyathuthuka, the 'township' of the adjacent town of Belfast, focusing only on the youth's religious views on 'respect'.

Because this was not part of the original research design of the YOMA project, new research questions were formulated. The first research question that directed this additional research was the following: 'what steals the youth's respect from them?' Possible answers informed by our YOMA research include the absence of healthy parent role models, poverty, hopelessness in terms of employment after having moved from agriculture to the hospitality industry, the breakdown of cultural values, the growing absence of respectful placement within (traditional or civil) marriage, a lack of education opportunities, drugs, authorities taking decisions without their consent or participation, and a location that is marginalised and isolated.

The second research question concerned the dominant discourses that convinced the youth of how respect was to be obtained. From previous YOMA research, again, it was asked: 'is it money, sex, violence or political activism?' Thirdly, then, we asked: 'what is the alternative discourse expected by the youth from the FBOs?'. Do they expect from the FBOs (only) to engage in giving moral direction, to preach against drugs and free sex, and to invite them to moral responsibility? To what extent do they expect the FBOs to cocreate spaces with them not only to think about 'morality' but also to engage in programmes on establishing healthy lifestyles?
The original research population for the YOMA project consisted of 46 young people between the ages of 18 and 24 years, and 15 resource people, are presenting both Sakhelwe and Emthonjeni. Although 'respect' was a generic theme in all the interviews, we are presenting the voices of five youngsters from Sakhelwe and three from Emthonjeni in this article based on the strength of their voices on the subject. They represented a mixed population of Ndebele, Swazi, Zulu and Pedi speakers, but shared a context of poverty and alienation. In addition, seven young people from Siyathuthuka were interviewed, who presented an alternative voice on 'respect' in light of their context that was more affluent.

The Municipal Report of Mpumalanga (2012) and the Reviewed Integrated Development Plan (2016) provide the most recent statistics on the harsh living conditions in Sakhelwe and Emthonjeni where there is an unemployment rate of $89 \%$. In Sakhelwe, the only work available for the youth is to work as waiters in the few restaurants in town. In Emthonjeni, there are almost no job opportunities after Asgang Chrome Factory closed down and Komati Mine scaled down on its workforce. Less than $20 \%$ of people are married or in any stable relationship, with $72 \%$ who have never been married, traditionally or in civil court. This is not because of an unwillingness to commit, but because of poverty preventing families to pay the bride price. Almost $30 \%$ of children who are of school-going age, do not attend school. Barely $1 \%$ of people have a tertiary qualification. Only half the population has access to electricity and running water.

Statistical information on the third 'township', Siyathuthuka in Belfast, is not readily available because the two sources mentioned in the previous paragraph (the Municipal Report and the IDP) have since been removed from the Internet. However, when we mapped the assets of all three these townships in 2013, Siyathuthuka showed a remarkable grade of affluency in comparison to Sakhelwe and Emthonjeni. Apart from the fact that Siyathuthuka is the size of Sakhelwe and Emthonjeni combined, it boasts of several schools, a variety of churches, a clinic, a community centre and (according to the Special Development Framework of the Emakhazeni Local Municipality 2017:48) a 'clear hierarchy of roads' is present. During previous research, all interviews that were held in Siyathuthuka were with young people who were engaged in tertiary education (Landman 2013). All this clearly points to the fact that young people in Siyathuthuka are exposed to living conditions and access to tertiary education that are not available in Sakhelwe and Emthonjeni.

\section{Research presuppositions and methods}

Swartz (2011:47-68) emphasises the following as ethical strategies when doing youth research: building equal relationships, conveying researcher subjectivity and displaying listening skills that hold the promise of future engagement in the challenges of the research participants.

In our research, we identified strongly with the ethical values described by Swartz, in combination with Rothney Tshaka's 
concern about how knowledge is produced in African contexts, a concern he expresses as follows (2016):

The reason for the continued hegemony of Western forms of knowledge production is a result of the inherent disregards that those in the West had for Africa and her purported inability to produce 'true knowledge'. (p. 92)

Our point of departure vis-à-vis methodology is described in the article 'Africanity and research: A case study in rural South Africa' (XXX). This entails a movement away from the Western academic focus on objectivity and verification towards an equal and auto-ethnographical relationship between the researchers and the research participants. In this research relationship, African contexts and voices matter, and words and stories are considered to be data with their own integrity. Consequently, in this article, the voices of the youth are presented as unmediated as possible under themes that have developed from their own words.

Interviewees remarked that the respect that they have experienced during the research process created a safe space for them to put 'respect' as a point of dialogue with the church. At the beginning of the YOMA interviews, when they were asked to describe their daily experiences in the township as well as their lived experience of the church, the theme of 'respect' did not surface. They only placed it on the table towards the end of the interviews when they were asked about their expectations of the church. By then, and by then only, enough trust was established between the researchers and the youth for them to speak out on the lack of respect that they experienced daily and their trust in the church to guide them on respect as a religious value.

From here the article, in describing the expectations of the youth vis-à-vis FBOs, will use the term 'the church' and not 'FBOs' because the research participants turned out to be exclusively Christian in spite of the efforts of the researchers to involve the Muslim youth who constitute a very small minority in the absence of other religions.

\section{Voices from marginalised rural youth}

The young people interviewed for this study mentioned 'respect' mainly in the sense of 'absence of respect'. They did not mention 'respect' as a lived experience in their relation to the church, but as an expectation enhanced by the research values to which they were exposed.

Consequently, the following themes in terms of 'absence of respect' were identified from the voices of these marginalised rural youths.

\section{Respect within restricted lifestyle possibilities}

Apart from the YOMA project, Landman has previously in Dullstroom-Emnotweni interviewed 50 children between the ages of 10 and 12 years, as well as 60 young people who have not secured a job in 10 and more years after finishing matriculation. In an article 'The future of our histories:
Young rural voices from Dullstroom-Emnotweni', Landman (2016:102) describes the clashes between the dreams of the early teenagers and the realities of the unemployed twentysomethings. On the one hand, the young learners between 10 and 12 years of age expressed their career hopes and dreams in terms of the needs of their marginalised society, that is, to become nurses, teachers and social workers. On the other hand, the twenty-somethings blamed their shattered dreams on the unavailability of tertiary education and the reality of HIV infection. They furthermore identified the causes of their socio-economic marginalisation as a lack of job and educational opportunities, a lack of agency and choice, an inability to escape from drugs and illicit sex - and a lack of respect from society and decision makers.

During research conducted for this paper, the youth in describing their daily lives implicitly answered the question 'what steals your respect from you?' in more or less the same way. Their lived experience of being marginalised is characterised by a lack of role models, choices, training and job opportunities, as well as an oversupply of boredom, drugs, liquor and sex.

Simulangiso (Sakhelwe, 07 December 2015) describes the living conditions in Sakhelwe as follows, indicating how this has led to disrespect towards the youth:

'Life is difficult. You can finish high school here but it's hard for me to go to university if you don't pass right away, it's hard for me. And if you look at bursary you will start here and there ... not even the municipalities are assisting us ... I think our government in this town doesn't care about us. Because they want us to be a slave until we die. ... This is one forgotten town.' $(19$, male)

This is supported and expanded by Goodwill (Sakhelwe, 08 December 2015):

'Our parents reject us; the teachers are beating us; we are two Grade 8 classes, one with 64 and the other with 74 learners. We are treated with no respect.' (21, male)

Another consequence of this disrespectfulness is the youth showing disrespect to authority as observed by Tshepo (Sakhelwe, 08 December 2015): 'Young people don't speak with and greet their teachers in a good way' (20, male).

Being disrespected and being disempowered go hand in hand, as in the words of Nonki (Emthonjeni, 08 April 2016):

'We are not used to voice our own opinions. Nobody seems to be interested in what we have to say. They take decisions on our behalf for what is good for us.' (19, female)

And again, the youth themselves confess to disrespecting themselves because of their disempowering circumstances. Nkosinathi (Sakhelwe, 07 December 2015) expressed this well:

'Life is difficult because one day you end up without studying at school. The people from here are allowed to not study, they are banking school and only like smoking, they're influencing bad things ... I like to sit at home and watch television and if I don't do that, I spend my time hanging with my friends and most I enjoy books.' (20, male) 
The same ambivalent confession comes from Zodwa (Sakhelwe, 07 December 2015): 'It is not good here in Sakhelwe. It is not good because many of us leave school and it is hard to get jobs and I'm drinking and smoking' (18, male).

With these living conditions leading to apathy and lack of self-respect, the youth themselves offer solutions, albeit superficial. However, the insight itself opens up a possible future, as expressed by Gladys (Sakhelwe, 08 December 2015): 'The people in our community, they must take their foolishness seriously and they must always do good things that can build up their future' (24, female). Sipho (Sakhelwe, 08 December 2015) points to both demanding and showing respect as alternatives to a surrender mentality amongst the youth: 'The most important thing is that they should respect, they should respect what is in their heart, so ja, they should respect' $(18$, male).

Within restricted lifestyle possibilities, the youth describe the frustrations related to their context and point to the consequences of the lack of respect and self-respect as disabling their dreams and inviting them to engage in a life of drugs, sex and games.

Next we look at how the churches are viewed to restore respect and present alternatives to a lifestyle of hopelessness.

\section{Respect as a religious value}

The youth interviewed mourn the 'absence of respect' in their community and point to the inability of role players such as parents and forms of governance - to teach this value by means of example. They therefore keep the possibility open that churches can fulfil this role. This is illustrated by their voices quoted here.

When asked why he would consider going to church, Sipho (Sakhelwe, 08 December 2015) said that when he was in the township and not away on visits, he would consider going to church because 'maybe you will get some respect (there at the church) or they would teach you to respect one another' $(18$, male). While Sipho may see respect as a general value to which the churches also subscribe, Goodwill (Sakhelwe, 08 December 2015) views respect as a value particular to the churches:

'My experience of the church is positive. Because people who go to church, they respect others. Yes, it is because they know the name of God. Those who don't go to church, they don't respect one another ... without respect, nothing is helping you.' (21, male)

According to Zandile (Sakhelwe, 08 December 2018), respect is a religious rule for which there is punishment or reward:

'Wherever you are, Jesus is watching you, if you are in church, if you are not in church. When you do something that is stupid, Jesus is always leading you on the way that can help you to be a good person one day. And you have to respect your parents so that the blessings can go and go, and you can live so many years ... If I do something bad, I can tell my pastor that I just need some prayers so that he can make me feel like a human being ... When the day comes that Jesus is going to take me, they will feel that it was nice to have had Zandile.' (23, female)

The Integrated Development Plan of eMakhazeni, the municipality of which our research population forms a part, indeed regards the FBOs as a stakeholder in the development of the youth (IDP2017-2022, par 1.2). The youth, not trusting the municipality, nevertheless confirm their confidence in the churches to develop the value of respect. This may be indigenous to local rural African youth. This acknowledgement of respect as a religious value, incidentally, is not in agreement with, for instance, youth in the United Kingdom voicing themselves as non-religious. Hemming (2017) cites the following reasons given by youth for not being religious:

$[D]$ isagreement with religious beliefs or practices, negative experiences of religion or religious authority figures, personal trauma such as death of a loved one, involvement in radical politics, commitment to science or logic, positive experiences of other atheists, and general indifference to religion or nonreligious socialisation. (p. 123)

From our, albeit limited, research, it seems that the youth confirm respect as a religious value in spite of their contextual hardships.

Interviews with two local pastors illustrate the churches internalising the responsibility of teaching respect given to them by the youth.

Pastor T leads an independent church in Machadodorp. He explains at length what his church does to make the youth feel respected. Only a few remarks are quoted here (Machadodorp, 08 April 2016):

'We are teaching issues that talks to them and their self-esteem. Like this evening I am teaching on careers and entrepreneurship, so that they change the mentality of wanting to be employed and always know they can do things on their own. And then also teach on leadership skills to say when you are a leader what is expected of you and so that you don't just follow all the time, but you take leadership roles.' (43, male)

Pastor C ministers in Belfast and in Dullstroom in a fastgrowing independent church consisting mainly of young people. He identifies a lack of belonging as the main reason for the low self-esteem of the youth (Belfast, 04 March 2016):

'The greatest need that I've seen with the young people of this area, especially in this area, is the lack of love, a sense of belonging the family unit is broken. It creates anger, it creates resentment and it creates them to have low self-esteem ... You must have creative ways to say this is a church - it is a family. It is a family full of love whereby everybody belongs because at the end of the day most young people they are talented, they are soccer players some of them, netball players and all those things ... In this church we accommodate different types of talents that can be exercised and you can be provided that opportunity.' (52, male)

In short, the young people in a context lacking moral agents identify the churches as a space where respect as a religious 
value is honoured, and where it can be taught and received. And traces of churches taking up this challenge have been found in the research areas.

Next we explore the need expressed by the youth for respect as a relationship and not as a rule, and the contribution of the churches to teach respect in such a way.

\section{Respect as relational and not authoritarian}

When the interviewer asked the question, 'What is nice about the church?', answers were given such as the following in which the youth viewed respect as embodied and taught as a relation in church: 'In church they teach you how to treat others with manners and with respect. You must have respect for others so that you can get the respect back' (Tshepo, 20, male, Sakhelwe, 08 December 2015); 'The way they talk to one another ...' (Sipho, 18, male, Sakhelwe, 08 December 2015); 'The church makes me humble and shows me how to respect myself and respect others and people's feelings' (Nonki, 19, female, Emthonjeni, 08 April 2016); 'The church teaches me how to respect myself and respect others and people's feelings' (Gugu, 21, female, Emthonjeni, 08 April 2016); and 'The church shows you which direction to go and to respect other people around you' (Themba, 18, male, Emthonjeni, 08 April 2016).

The quote from which we took the title of this article comes from Simulangiso (Sakhelwe, 07 December 2015):

\begin{abstract}
'If you go to church maybe you will get some respect or you must respect one another ... who go to church, they do respect. Yes and then they know the name of God. Those who do not go to church, they do not respect one another.' (19, male)
\end{abstract}

Pastor T explains what he understands about respectfully dealing with the youth, setting an example of how 'to do respect':

'I remove the cap so I just play and get my hands dirty with them, so then sometimes then I will initiate the talks at their level. I mean like sometimes we are cleaning in the church and then I will clean with them and whilst we are cleaning I will say "I heard you are getting married, do you think you must get married hey what's happening?", then one gets the chance to say okay let me put some sense in this issue but informally.' $(43$, male)

From these voices what is said by Smith (2012) seems to be at least partially relatable to the youth's expectation from and experience of the churches in the research area:

From an indigenous perspective ethical codes of conduct serve partly the same purpose as the protocols which govern our relationships with each other and with the environment. The term 'respect' is consistently used by indigenous people to underscore the significance of our relationships and humanity ... Respect is a reciprocal, shared, constantly interchanging principle which is expressed through all aspects of social conduct. (p. 125)

If respect as a religious value that as a relation and not a rule appeals to the youth, the question remains if this definition of 'respect' can work through to society and become a community asset. This wish as expressed by the youth will now be investigated through their own voices.

\section{Respect as not yet a community asset}

From the descriptions of the everyday life of young people, it becomes clear that the community ethos in Sakhelwe and Emthonjeni is not to have aspirations and that hopelessness is internalised.

When being asked 'so what are young people doing the whole day in Sakhelwe?' answers displaying the lack of a vision towards the future were given: Zodwa (Sakhelwe, 07 December 2015) says: 'They are just walking around, smoking drugs, ja. Dealing with friends or sleeping with something that means nothing to them. Just they are dead' (18, male); Simulangiso (Sakhelwe, 07 December 2015) depicts the youth as 'Waiting for the sunset' (19, male); Sarah (Sakhelwe, 07 December 2015) sadly points to the lack of vision amongst the youth:

'Young kids are having babies, they are wasting their future. There is no more future there ... They don't care about their future. Because they always, when I am at home I find the two litre coke on the table and lots of bread ... kids who are always eating nice, they are not as sure what they want. They want nothing. But if you don't have nothing at all to put on the table at home, then you have to go out and hustle.' (20, female)

To the question of the interviewer 'why all the businesses in Sakhelwe belonged to non-South Africans', Simulangiso (Sakhelwe, 07 December 2015) gave a significant answer:

'You open a shop, you sell bananas and then the customer can only pay for one so the one customer take one banana then tomorrow you won't open. You will say 'yesterday, I only sold one banana, why? Then those Pakistani, they are patient! They are very patient. I think we lack patience.' $(19$, male)

Pastor C explains the challenges of a small town as follows:

'The problem with small communities is that there is nothing that challenges them. There is nothing that inspires them ... if I drink a lot or if I finish six beers or twenty beers in a week then I am the best person. That is the only motivation that they have, there are no proper sport facilitates, no cinemas and all those things whereby they can know art and culture activities ... I speak about people like Joseph, people like David who came from very difficult backgrounds ... So like that woman with an issue of the blood. Everybody had written her off. Sick, lost everything. But she sat in their heart. She sat in their heart. What is very important is not what people are saying to you, it is what you are saying to yourself.' (52, male)

Khanyi (Sakhelwe, 08 December 2015) views self-respect as an asset that can redeem the community:

'The young people of our community, they must not have no self-esteem, they must believe in themselves ... They must have self-development to deliver those things in life (which will earn them respect).' (22, female)

In this section, the youth respecting themselves are seen as a community asset, albeit one that is still missing. However, intangible assets such as self-respect need to be converted 
into tangible assets. Can the church, according to the youth, comply with this demand?

\section{Respect as envisaged as tangible outcome}

The religious identity of the youth interviewed manifests in two distinctive though integrated forms. On the one hand, the youth express their religiosity in pietistic terms envisaging the church as a space for praying and moral teaching. On the other hand, a majority implicitly and a minority explicitly insisted on the church embodying its language in tangible outcomes. The youth themselves curb their expectations of the churches because of the latter's obvious poverty and inability to provide substantial assistance. Some of the churches are in such a state of dilapidation that the young people feel embarrassed to attend.

Nomsi (Emthonjeni, 08 April 2016) expresses her dissatisfaction with the idea that the church is there for praying only as follows:

'According to my understanding, the church and the community doesn't do anything. The only thing that the churches do for us, they just pray for a better life. But then there are people who are outside, they are needy. But they don't get what they need exactly. But they continue praying.' (19, female)

And Gugu (Emthonjeni, 08 April 2016) recalls the church (only) fulfilling its task to teach morals:

\begin{abstract}
'It teaches me about morals and values and how must I behave myself as a woman and what is expected from me from God ... what is expected of me from God that I mustn't have pride, I mustn't look down on other people, I must help those who need help, I must help where I can ja that is what the church teaches me.' (21, female)
\end{abstract}

The youth time and again defined their main need to be the accessibility to tertiary education and the availability of jobs. As Khosi (Emthonjeni, 08 April 2016) puts it:

'Okay, my intake I think the churches should combine themselves, especially in our community. They should combine and raise funds for the youth in developing our skills and they should take part in the institutions where the bursary are funded so that they can allocate them to us, the youth.' (24, male)

Vhumi (Sakhelwe, 08 December 2015) testifies to some success from the church's side:

'Yes sometimes with church we do have opportunities, just like last year when Prof Landman, said to us that there are bursaries. She came with the forms and gave those ones who were going to university that year, to fill out the forms. So she is part of this church so this church helps those students or learners who wanted to go to University at that time.' (20, male)

Zodwa (Sakhelwe, 07 December 2015) expresses his frustration of not even having basic computer skills:

'Actually I don't know a computer. Now who will teach me? Ja, you can't do something that you don't know. Someone, she or he have to teach you and show you how to do this and that.' $(18$, male)

\section{Dominant discourses on what constitutes 'respect' for marginalised rural youth compared to more empowered youth}

The voices of the youth in the impoverished townships of Sakhelwe and Emthonjeni quoted above reveal their need to be respected, as well as the self-awareness that they need both to gain self-respect and to respect the albeit incompetent role models in their communities. They also disclose the reasons for this lack of respect and self-respect: dire living conditions, no hope in the future, inadequate role models, limited respect from institutions like schools and the municipality, no access to tertiary education and jobs, and restricted participation in the making of decisions on all levels of private and public life.

Consequently, the dominant discourse that rules the lives of youth in Sakhelwe and Emthonjeni is that drugs, liquor and sex constitute respect. As Pastor T puts it:

'The child grant, I think to certain extend to some it has an effect because if they are not working it will serve as an income and also they have nothing to do, so sex becomes a hope.' $(43$, male)

Violence and participation in protest action earn respect. For more detail on this, see Swartz (2014:324-342).

The master narratives regulating the perceptions of young people in poor townships about 'respect' convince the youth that respect is earned through money, sex, violence and political activism. How does this compare to a township where the youth live in more affluent circumstances?

On 08 November 2017, interviews were held with Lindiwe, Lungile, Maria, Nelly, Nokuthula, Nompumelelo and Nomsa in Siyathuthuka. The people of Siyathuthuka work in the nearby mines and the township is more affluent compared to Emthonjeni and Sakhelwe where unemployment may be as high as $89 \%$.

'Respect' is not a dominant theme amongst these youngsters, and they do not see themselves as victims of 'a lack of respect'. When asked when they do not feel respected, they give answers as follows: 'when someone blames me wrongly' or 'when I do not get credit for something I have done' or 'when somebody makes a decision on my behalf without my consent'.

When asked when they feel especially respected, they report personal highpoints such as 'on my graduation day', 'when I achieved my matric certificate' or 'at my matric dance'.

In short, the young people of Siyathuthuka show a delightful sense of identity, self-worth and self-respect, in contrast to the marginalised youth of Sakhelwe and Emthonjeni for whom the lack of respect shown to them constitutes a major issue. 'Nobody will dare to disrespect $\mathrm{me}^{\prime}$, one of the interviewees from the more resource-rich Siyathuthuka said. 
The following can be considered differences on the issue of 'respect' between the two groups of youths:

- The more affluent youth do not report institutionalised disrespect towards them, but only a lack of respect from individuals such as their classmates, while the impoverished youth complain about schools, the municipality and senior members of the community not respecting them.

- The impoverished youth single out the church as a possible alternative to address institutionalised disrespect, while the more affluent youth see respect not as a religious value, but a human rights discourse.

- The more privileged youth do not expect the church, but the governance (municipality) to create jobs and provide opportunities for skills development that do not focus on the mining industry only. Their need for jobs is more than tertiary education to which they have access as part of being more affluent families. They do not see the church as providing these opportunities, or other tangible assets, as the impoverished youth do because of the latter's desperation in communities where providers are absent.

- While the impoverished youth feel that the church can and should teach all 'to do respect', the more affluent youth blame the church for giving more respect to older than to younger people, and for giving more attention to church procedures than to people.

- The more affluent youth honour the role of the church in providing intangible assets, such as faith and love, but feel that the church has a different role to play to that of the municipality. However, they feel that the church can provide a crèche and a beauty centre from which the youth can benefit. Their concern is not primarily for the church to provide for and develop poorer young people although, when this is brought to their attention, they feel that the church indeed should reach out to the less privileged.

\section{Conclusion: The churches' involvement in the embodiment of respect vis- à -vis the voices of the youth}

This study listened to the voices of the youth in the marginalised townships of Sakhelwe and Emthonjeni and profiled their voices against that of the youth in the more affluent township of Siyathuthuka. The themes through which the marginalised youth wishes to communicate their need 'to do respect' to the churches were deduced from their voices, which are summarised as follows:

1. The marginalised youth wish to communicate to the churches that their lifestyle possibilities are limited and infringe on their rights to demand respect from the community. Poverty and societal morals also impact their self-respect and have convinced them that sex, drugs and easy money are the only ways of earning respect in society. The expectation is that the churches will create an enabling community, both in and outside the church, by teaching people 'to do respect' and to lead by example.

2. The marginalised youth wish to furthermore communicate to the churches that they honour respect as a religious value and expect from the churches to embody this in teaching in the disappointment of other moral agents.

3. The marginalised youth also express appreciation that their experience of the churches' handling of respect is one of relationship building and not of punishment and ruling.

4. The marginalised youth display a conflicting religious identity by viewing the church from a pietistic perspective as a praying and morally fixated institution, while covertly yearning for the embodiment of their needs through the church in terms of tangible assets and skills.

5. Compared to the more affluent rural youth, the marginalised youth give a more pronounced role to the church to provide tangible assets to enhance respect for the youth.

By involving job creation and tertiary education in their dealings with the youth, the church has to become a role model in not only teaching respect as a religious value but also by 'doing respect'.

\section{Ethical consideration}

Ethical clearance to conduct this research was obtained from the University of South Africa (ethical clearance number: 2014_CHS_(Staff)_USSD_003).

\section{Acknowledgements Competing interests}

The authors declare that they have no competing interests with regard to the writing of this article.

\section{Authors' contributions}

The two authors, C.L. and H.Y., contributed equally to the research conducted for and the writing of the article.

\section{References}

Census 2011 Municipal Report, Mpumalanga, 2012, Statistics South Africa, Pretoria, viewed 25 April 2018, from www.statssa.gov.za

Hemming, P.J., 2017, 'Childhood, youth and non-religion: Towards a social research agenda', Social Compass 64(1), 113-129. https://doi.org/10.1177/003776861 6683333

IDP eMakhazeni, 2016, Reviewed integrated development plan, final, viewed 25 April 2018, from http://www.emakhazeni.gov.za/IDP_EMAKHAZENI-LM2016-17.pdf

Landman, C., 2013, Ministerial practice and service delivery in the eMakhazeni Municipality, unpublished paper delivered at the Society for Practical Theology in Southern Africa in January 2013.

Landman, C., 2016, 'The future of our histories: Young rural voices from DullstroomEmnotweni', Oral History Journal of South Africa 2(1), 102-113.

Landman, C. \& Yates, H., 2017, 'Africanity and research: A case study in rural South Africa', HTS Theological Studies 73(4), a4775. https://doi.org/10.4102/hts. v73i 4.4775 
Landman, C. \& Yates, H., 2018, 'Do the FBOs know where they are going? Listening to the voices of rural youth in the eMakhazeni Local Municipality', unpublished chapter submitted for the YOMA project manuscript, Stuck in the margins? Young people and faith-based organisations in South African and Nordic localities,

Sennott, C. \& Majola, S.A., 2017, 'Behaving well': The transition to respectable womanhood in rural South Africa', Culture, Health \& Sexuality 19(7), 781-795. https://doi.org/10.1080/13691058.2016.1262062

Smith, T.L., 2012, Decolonizing methodologies, 2nd edn., Zed Books, London.

Special Development Framework, Emakhazeni Local Municipality 2017.
Swartz, S., 2011, "Going deep" and "giving back": Strategies for exceeding ethical expectations when researching amongst vulnerable youth', Qualitative Research 11(1), 47-68. https://doi.org/10.1177/1468794110385885

Swartz, S., 2014, 'The rules of violence: A perspective from youth living in South African townships', Journal of Youth Studies 17(3), 324-342. https://doi.org/10.10 80/13676261.2013.815699

Tshaka, R.S., 2016, 'How can a conquered people sing praises of their history and culture? Africanization as the integration of inculturation and liberation', Black Theology 14(2), 91-106. https://doi.org/10.1080/14769948. 2016.1185841 